\title{
The Influence of Culture Capital and Work Ethics on Productive Behavior of New Business Candidates
}

\author{
$1^{\text {st }}$ Arfian \\ Faculty of Psychology \\ Universitas Padjadjaran, Bandung, Indonesia \\ Universitas Azzahra, \\ Jakarta, Indonesia \\ arfian16001@mail.unpad.ac.id \\ $3^{\text {rd }}$ Marina Sulastiana \\ Faculty of Psychology, \\ Universitas Padjadjaran, \\ Bandung, Indonesia \\ marina.sulastiana@unpad.ac.id
}

\author{
$2^{\text {nd }}$ Anissa Lestari Kadiyono \\ Faculty of Psychology, \\ Universitas Padjadjaran, \\ Bandung, Indonesia \\ anissa.lestari@unpad.ac.id
}

\author{
$4^{\text {th }}$ Diana Harding \\ Faculty of Psychology, \\ Universitas Padjadjaran, \\ Bandung, Indonesia \\ diana.harding@unpad.ac.id
}

\begin{abstract}
Indonesia will enter the demographic bonus in 2045, where entrepreneurial skills are needed to deal with the issue of demographic bonus. On the other side, the business competition is quite tight, so it is demanded to provide superior human resources in the business field. One effort is to increase the productive behavior of prospective entrepreneurs. The purpose of this study was to determine the effect of cultural capital and work ethic on the Productive Behavior of prospective new entrepreneurs. The study population numbered 90 new prospective entrepreneurs, the same sample with the population. Quantitative research methods and data analysis techniques are being used simultaneously and partial regression analysis. The results showed that simultaneous cultural capital and work ethic had a significant effect on the productive behavior of prospective new entrepreneurs. Cultural capital influences the productive behavior of prospective new entrepreneurs. Work ethic has a significant effect on the productive behavior of prospective new entrepreneurs. The conclusion of productive behavior research is influenced by cultural capital and work ethic.
\end{abstract}

Keywords-cultural capital, work ethic, productive behavior and new entrepreneurship

\section{INTRODUCTION}

Indonesia in 2045 is predicted to reach 318.96 million people. The number consists of 160.21 million women and 158.75 million men. The number of productive population (15-64 years) reaches $65.2 \%$. The population that has not been productive (1-14 years) is $20.7 \%$ and unproductive reaches $14.1 \%$. This means that the dependency ratio of Indonesia's population reaches $53.4 \%$. This needs to be watched out for so that it does not become a burden for future generations [1].

The solution for Indonesia will enter the demographic bonus in 2045 is to create entrepreneurs, because the increase in population will serve as a potential domestic market. Opportunities to become entrepreneurs in Indonesia are open wide, cultural capital and abundant natural resources also support to become potential entrepreneurs. This needs entrepreneurial skills needed to deal with the demographic bonus. On the other side, the business competition is quite tight, so it is demanded to provide superior human resources in the business field. One effort is to increase the productive behavior of prospective entrepreneurs. Factors that encourage increased productive behavior seen from the cultural capital and work ethic.

According to Bourdieu, cultural capital in the form of symbolic is not like economic capital in the form of material [2]. Science is one of cultural capitals [3]. Cultural capital is created when values, traditions, beliefs, and language become capital. Every individual is born in their own culture which is influenced by their family and social environment.

Miller, Woehr, and Hudspeth work ethic as a set of attitudes and beliefs that influence work behavior. These attitudes and beliefs will influence work behavior so that individuals consistently display behaviors that support productivity [4]. High productivity can overcome the demographic bonus that will be experienced by Indonesia in 2045 .

\section{THEORETICAL REVIEW}

\section{Productive Behavior}

Understanding of behavior according to Gibson, Ivancevich, and Donnely is a function of interactions between an individual and his environment. Productive behavior means a function of an individual's interaction with his environment that can productively produce outcomes that can help him adjust effectively to the challenges of his environment [5].

The characteristics of highly productive employees are as follows: 1). More than fulfilling job qualifications. Qualifications are considered fundamental to the job. It is considered that high productivity is not possible without the right qualifications. 2). Motivation. This is a driving factor why individuals direct their energy to behave. 3). Have a 
positive work orientation. A person's attitude towards work assignments. 4). Can get along effectively. The ability to establish positive interpersonal relationships. and 5). Adult. The ability and willingness of a person to be responsible for carrying out work [6].

\section{Work Ethic}

Miller in Miller, Woehr, and Hudspeth defines work ethic as a set of attitudes and beliefs that affect work behavior. This attitude and belief will affect work behavior so that individuals consistently display behaviors that support productivity [4].

Dimensions of work ethic according to Miller, et al. [4], Ryan and Tipu [7], Hite, Daspit, Dong, and Zueni [8], Van Ness, Raymond, Melinsky, Kimberly, Cheryl and Seifert, [9], Ryan, and Tipu, [7], who adopted Max Weber's concept of the dimensions of work ethic formation which are summarized into seven dimensions through Multidimensional Work Ethic Profile (MWEP) as follows: 1 ). Self reliance, that is the attitude of individuals to try not to depend on others in completing their daily work. 2). Morality/ethics, Individual belief in a fair and moral work environment. 3). Leisure, the attitude of individuals to be pro towards leisure activities and confidence in the importance of activities other than work. 4). Hard work, individual confidence in the virtues of hard work. 5). Centrality of work the belief of individual actors about the importance of work. 6). Wasted time, the belief of individual actors to reflect the active and productive use of time. 7). Delay of gratification, individual orientation towards the future and delay gratification.

\section{Cultural Capital}

Cultural capital is symbolic in form unlike material capital in the form of economic capital [2]. Science is a cultural capital [3]. Cultural capital is created when values, traditions, beliefs and language become capital. Cultural capital has three sub-types, namely embodied, objectified and institutionalized.

Embodied cultural capital consists of knowledge acquired consciously and passively passed on, through socialization through culture and tradition. is obtained from time to time, because it depends on someone's habitus (character and way of thinking), which in turn, becomes more receptive to similar cultural influences. The objectification of cultural capital (objectified) consists of a person's property (for example a work of art, scientific instruments, etc.) that can be transmitted as an economic advantage (buying and selling) that symbolically conveys ownership of certain cultural capital, because it has these goods. However, in the possession of an art work (objectification of cultural capital), a user or owner of the work of art, understands the historical significance and foundation of the previous cultural capital. Institutional cultural capital consists of formal institution recognition of one's cultural capital, usually in the form of academic or professional qualifications. The recognition of a formal institution facilitates the exchange of cultural capital with economic capital, by presenting practical solutions in which sellers can describe their cultural capital to buyers.

A person's habits consist of intellectual dispositions instilled in him by the family and family environment, and are manifested according to the nature of that person. Thus, the social formation of one's habitus is influenced by the family, by objective changes in social class, and by social interactions with others in daily life. Cultural capital conceptually explains the difference between performance and achievement levels.

\section{Relationship between Cultural Capital and Work Ethic} with Productive Behavior

Work ethic refers more to the quality of personality that is reflected through the full performance in various dimensions of life. Thus the work ethic is more an internal condition that encourages and controls behavior towards the realization of ideal work quality. The quality of work performance and work results are largely determined by the quality of this work ethic. As an internal condition, work ethic contains several elements including: (1) work discipline (2) attitude towards work, (3) work habits. With work discipline, a worker will always work in consistent patterns to do well according to his demands and abilities. A person's habits consist of intellectual dispositions instilled in him by the family and family environment, and are manifested according to the nature of that person. Thus, the social formation of one's habitus is influenced by the family, by objective changes in social class, and by social interactions with others in daily life; In addition, a person's habitus also changes when he changes his social position on the field. Cultural capital conceptually explains the difference between performance and achievement levels

Based on the description above, the major hypothesis and minor hypothesis are formulated as follows:

1). The major hypothesis, There is the influence of cultural capital and work ethic on the productive behavior of prospective new entrepreneurs.

2). Minor hypothesis, (1) there is an influence of cultural capital on the productive behavior of prospective new entrepreneurs. (2) there is an influence of work ethic on the productive behavior of prospective new entrepreneurs.

\section{RESEARCH METHODOLOGY}

This research was conducted on the trainees of New Entrepreneur Candidates in Pemalang, Pekalongan, Banyuwangi and Aceh Tamiang with a total of 90 participants, with the same population as the sample. Data collection is carried out when conducting training for prospective new entrepreneurs using a Likert scale model. There are 3 scales used, namely scale of productive behavior, scale of work ethic and scale of cultural capital. Data were analyzed using simultaneous regression with the SPSS 24 program.

\section{ANALYSIS RESULTS}

Reliability test results measuring instrument. The work ethic variable obtains Cronbach's Alpha value is 0.829 and cultural capital is 0.649 . So that the work ethic and cultural capital variables have good reliability. The test results of measuring instrument Reliability of productive Behavioral Variables obtained Cronbach's Alpha value is 0.746 . So the variable productive behavior has a pretty good reliability.

Table.1. Results of Multiple Linear Regression Analysis 


\begin{tabular}{|c|c|c|c|c|c|c|}
\hline & & $\begin{array}{r}\text { Unstan } \\
\text { Coeff }\end{array}$ & $\begin{array}{l}\text { irdized } \\
\text { ients }\end{array}$ & $\begin{array}{l}\text { Standardized } \\
\text { Coefficients }\end{array}$ & & \\
\hline & Model & $\mathrm{B}$ & $\begin{array}{l}\text { Std. } \\
\text { Error }\end{array}$ & Beta & $\mathrm{t}$ & Sig. \\
\hline 1 & (Constant) & 17.782 & 11.722 & & 1.517 & .133 \\
\hline & $\begin{array}{l}\text { Cultural } \\
\text { capital }\end{array}$ & .608 & .145 & .392 & 4.200 & .000 \\
\hline & $\begin{array}{l}\text { Work } \\
\text { Ethic }\end{array}$ & .233 & .080 & .273 & 2.927 & .004 \\
\hline
\end{tabular}

Table Information: Coefficients

The results of multiple linear regression analysis of the work ethic and cultural capital variables with productive behavior variables to determine the direction of the relationship between the independent variable and the dependent variable.

\section{A. Double Correlation Analysis (R)}

Table 2. Results of multiple correlation analysis

\begin{tabular}{|c|c|c|c|c|}
\hline \multicolumn{5}{|c|}{ Model Summary } \\
\hline Model & $\mathbf{R}$ & R Square & Adjusted R Square & $\begin{array}{l}\text { Std. Error of the } \\
\text { Estimate }\end{array}$ \\
\hline 1 & $.512^{\mathrm{a}}$ & .262 & .245 & 6.71012 \\
\hline
\end{tabular}

Based on the table above, an $\mathrm{R}$ figure of 0.512 is obtained. This shows that there is a moderate relationship between work ethic and cultural capital on productive behavior.

\section{B. Determination Analysis (R2)}

Based on the table. above is obtained R2 (R Square) of 0.262 or $(26.2 \%)$. This shows that the percentage contribution of the influence of the independent variable (Work Ethic and Cultural Capital) to the dependent variable (Productive Behavior) by $26.2 \%$. Or the variation of the independent variables used in the model (Work Ethos and Cultural Capital) is able to explain $26.2 \%$ of the variation of the dependent variable (Productive Behavior). While the remaining $73.8 \%$ is influenced or explained by other variables not included in this research model.

\section{Joint Regression Coefficient Test (Test F)}

Table. 3. Test Results F

\begin{tabular}{|c|c|c|c|c|c|c|}
\hline & Model & $\begin{array}{l}\text { Sum of } \\
\text { Squares }\end{array}$ & df & $\begin{array}{c}\text { Mean } \\
\text { Square }\end{array}$ & $\mathbf{F}$ & Sig. \\
\hline \multirow[t]{3}{*}{1} & Regression & 1390.553 & 2 & 695.276 & 15.442 & $.000^{\mathrm{b}}$ \\
\hline & Residual & 3917.236 & 87 & 45.026 & & \\
\hline & Total & 5307.789 & 89 & & & \\
\hline
\end{tabular}

Table Information: ANOVA

The results of the simultaneous regression analysis can be seen the value of $\mathrm{F}$ as in table 3 .

Hypothesis:

Ho: There is no significant influence between work ethos and cultural capital together on productive behavior.

Ha: There is a significant influence between work ethos and cultural capital together on productive behavior.
Based on table 3. obtained an F count of 15.444 with a significance of 5\% using a confidence level of $95 \%, \alpha=5 \%$, df 1 (number of variables-1) $=2$, and df 2 (nk-1) or 90-2-1 = 87 ( $\mathrm{n}$ is the number of cases and $\mathrm{k}$ is the number of independent variables), the results obtained for $\mathrm{F}$ table amounted to 3.101. The test criteria are that Ho is accepted if $\mathrm{F}$ arithmetic $<\mathrm{F}$ table and Ho is rejected if $\mathrm{F}$ arithmetic $>\mathrm{F}$ table. Then the calculated $F$ value $>F$ table $(15.444>3.101)$, then Ho is rejected. This means that there is a significant influence between work ethos and Cultural Capital together on productive behavior. So from this case it can be concluded that the work ethos and Cultural Capital together influence the productive behavior.

\section{Partial Regression Coefficient Test ( $t$ Test)}

Table.4. Test Results t

\begin{tabular}{|c|c|c|c|c|c|}
\hline \multirow[b]{2}{*}{ Model } & \multicolumn{2}{|c|}{$\begin{array}{l}\text { Unstandardized } \\
\text { Coefficients }\end{array}$} & $\begin{array}{l}\text { Standardized } \\
\text { Coefficients }\end{array}$ & \multirow[b]{2}{*}{$\mathbf{t}$} & \multirow[b]{2}{*}{ Sig. } \\
\hline & & $\begin{array}{l}\text { Std. } \\
\text { Error }\end{array}$ & Beta & & \\
\hline (Constant) & 17.782 & 11.722 & & 1.517 & .133 \\
\hline $\begin{array}{c}\text { Cultural } \\
\text { capital }\end{array}$ & .608 & .145 & .392 & 4.200 & .000 \\
\hline Work Ethic & .233 & .080 & .273 & 2.927 & .004 \\
\hline
\end{tabular}

\section{1) Testing the coefficient regression variable Work ethic}

Based on the table.4. obtained $t$ value of 2.927 , with a significance using $\alpha=5 \%$. Then determine $\mathrm{t}$ distribution table $\mathrm{t}$ is sought at $\alpha=5 \%: 2=2.5 \%$ (2-tailed test) with degrees of freedom (df) nk-1 or $90-2-1=87$ ( $n$ is the number of cases and $\mathrm{k}$ is the number independent variable). With 2sided testing (significance $=0.025$ ) the results obtained for $\mathrm{t}$ table amounted to 1.988. The test criteria are Ho is accepted if $-\mathrm{t}$ table $<\mathrm{t}$ count $<\mathrm{t}$ table and Ho is rejected if $-\mathrm{t}$ count $<-\mathrm{t}$ table or $t$ count $>t$ table. So the value of $-t$ count $>-t$ table $(2.927>1.988)$ then Ho is rejected. Then Ha is accepted, meaning partially there is a significant influence between Work Ethos with productive behavior. So from this case it can be concluded that partially the work ethic influences the productive behavior of the trainees of prospective new entrepreneurs.

\section{2) Testing the regression coefficient of the Cultural Capital variable}

Based on the table 1. obtained $\mathrm{t}$ value of 4.200 , with significance using $\alpha=5 \%$. Then determine $\mathrm{t}$ distribution table $\mathrm{t}$ is sought at $\alpha=5 \%: 2=2.5 \%$ (2-tailed test) with degrees of freedom (df) nk-1 or 90-2-1 = 87 ( $\mathrm{n}$ is the number of cases and $\mathrm{k}$ is the number independent variable). With 2sided testing (significance $=0.025$ ) the results obtained for $\mathrm{t}$ table amounted to 1.988. The test criteria are Ho is accepted if $-\mathrm{t}$ table $<\mathrm{t}$ count $<\mathrm{t}$ table and Ho is rejected if $-\mathrm{t}$ count $<-\mathrm{t}$ table or $t$ count $>t$ table. So the value of $-t$ count $>-t$ table $(4.200>1.988)$ then Ho is rejected. Then Ha is accepted, meaning that partially there is a significant influence between cultural capital and productive behavior. So from this case it can be concluded that partially cultural capital influences productive behavior in the trainees of prospective new entrepreneurs. 


\section{DISCUSSION}

Work ethic and Cultural Capital together influence productive behavior. Thus the major hypothesis has been proven to significantly influence the variables of work ethic and cultural capital and productive behavior. Thus the hypothesis is accepted so that the work ethic and cultural capital can be used as predictors of productive behavior. There is a significant influence between work ethic and productive behavior. so it can be concluded that work ethic partially influences productive behavior in the trainees of prospective new entrepreneurs. These results are in accordance with the results of Rachmawati's (2016) research on a descriptive study of the work ethic of Micro and Small Medium Enterprises entrepreneurs in the Cibaduyut shoes industry in Bandung. The results of this study indicate that the work ethic of Micro and Small Business Entrepreneurs is in the high enough category, meaning that in general Micro and Small Business Entrepreneurs have confidence in the 7 dimensions of work ethic formation. This can increase productive behavior which in turn can increase business productivity [10].

There is a significant influence between cultural capital and productive behavior. so it was concluded that partially cultural capital influenced the productive behavior of the trainees of prospective new entrepreneurs. This finding is in line with the results of the research of Muhammad Irfan Hilmi (2015) The Effect of Interpersonal Communication Quality, Achievement Motivation and Creativity on Productive Behavior of Members (Study in Self-Help Groups Community PNPM Mandiri Urban Program in the District of Ujungberung, Bandung). Based on the results of the study it was found that there was an influence of the quality of interpersonal communication, achievement motivation and creativity simultaneously on the productive behavior of members showing positive prices [11]

\section{CONCLUSION}

The work ethic and cultural capital have a positive and very significant relationship with the productive behavior of trainees of prospective new entrepreneurs. This means that the work ethic and cultural capital have an effect on the productive behavior of the trainees of prospective new entrepreneurs. Work ethic and cultural capital as independent variables can be used as predictors in this study. Work ethic influences productive behavior and cultural capital influences productive behavior in trainees of prospective new entrepreneurs.

\section{REFERENCES}

[1] https://databoks.katadata.co.id/datapublish/2018/10/03/ 100-tahunindonesia-merdeka-jumlah-penduduk-mencapai -319-juta-jiwa.

[2] Bourdieu, Pierre, "The Forms of Capital", dalam Richardson, J. G., Handbook of Theory and Research for The Sociology of Education, Westport, Conn.: Greenwood Press, 1986.

[3] Bourdieu, Pierre, Reproduction in Education, Society and Culture. London: Sage, 1990.

[4] Miller, M. J., Woehr, D. and Hudspeth, N, "The Meaning and Measurement of Work Ethic: Construction and Initial Validation of a Multidimensional Inventory." Journal of Vocational Behavior 60: 451- 489, 2002.
[5] Gibson, James L, John M. Ivancevich dan James H. Donnelly, Organizations: Behavior, Structure and Process, McGraw-Hill Companies Inc, Boston, 2000.

[6] Ranftl, Robert M, A Productivity Profile Guidelines to Productive Management: Profiles of a productive employee, organization, and manager. Management Notes: Productivity Issue. Administrative Management Staff. Vol. 23 - Issue No.2 November 1979.

[7] Ryan, James C., dan Tipu, Syed A. A, An Empirical Alternative to Sidani and Thornberry's (2009). 'Current Arab Work Ethic': Examining the Multidimensional Work Ethic Profile in an Arab Context. J Bus Ethics, 2016, 135:177-198 DOI 10.1007/s10551-0142481-4.

[8] Hite, Dwight M., Daspit, Joshua J., and Dong, Xueni, Examining the influence of Transculturation on work ethic in the United States. Cross Cultural Management Vol. 22 No. 1, pp. 145-162, 2015.

[9] Van Ness, Raymond K,. Melinsky, Kimberly,. Buff, Cheryl and Seifert, Charles F, Work Ethic: Do New Employees Mean New York Values. Journal of manageral issues vol. XXII Number 1 Spring : 10-34, 2010

[10] Maretha Rachmayanti, Studi Deskriptif Mengenai Etos Kerja Pada Pelaku UMKM Sentra Industri Sepatu Cibaduyut Kota Bandung. Skripsi. Universitas Padjadjaran Bandung, 2016.

[11] Muhammad Irfan Hilmi, Pengaruh Kualitas Komunikasi Interpersonal, Motivasi Berprestasi dan Kreativitas Terhadap Perilaku Produktif Anggota (Studi pada Kelompok Swadaya Badan Keswadayaan Masyarakat Program PNPM Mandiri Perkotaan di Kecamatan Ujungberung Kota Bandung), 2015. 